\title{
LEGAL REGULATIONS REGARDING THE IMPACT EVALUATION METHODOLOGY OF STRUCTURAL AND COHESION FUNDS
}

\section{F- A. POPESCU}

\section{Felix-Angel POPESCU}

Agora University of Oradea, Faculty of Legal and Administrative Sciences

No. 8, Tineretului Square Street, Oradea, Romania

E-mail felixangelpopescu@gmail.com

\begin{abstract}
:
Establishing a legislative framework for addressing an appropriate methodology for assessing the impact of Structural and Cohesion funds, in all 3 evaluation phases (ex-ante, intermediate and ex-post), is necessary both for users of these funds (the resort ministry, the intermediary bodies, the final beneficiaries - from an EU Member State) as well as for researchers on this topic. The stage of the knowledge in the field of the impact of these funds on each EU Member State economy narrows when the effects of the implementation of projects at regional, county and urban - rural level are discussed.
\end{abstract}

KEYWORDS: impact, evaluation, methodology, Structural, Cohesion, funds.

\section{INTRODUCTION}

The European Commission has struggled to reduce the number of exceptions to the community rules regarding the legal obligation for evaluation and impact assessment. Community funding is not making any deviation from the rule, as in the recent years, there was consolidated a thorough primary legislation ${ }^{1}$ acknowledged by each Member State concerning the allocation and implementation of intra-community financial assistance.

However, there is a lack of impact assessments of the European funded projects across all Member States, which would serve to inform on 'who will be affected and how, ensuring economic, social and environmental impacts are considered together'². Although such necessities are systematically discussed in the decisional process between the European Parliament, the Council and the European Commission, there are some procedural gaps and time laps until the Member States take over the community acquis in this concern. In the international legal literature regarding the regulations of impact evaluation, there are some external institutions which help towards a better understanding of the evolutionary perspectives which define impact assessments as an important evaluation tool in the European Union decisional process - the World Bank ${ }^{3}$, the Organization for Economic Cooperation and Development $^{4}$, as well as private consulting networks ${ }^{5}$ or companies ${ }^{6}$.

\footnotetext{
${ }^{1}$ https://ec.europa.eu/regional_policy/ro/information/legislation/regulations/ [01.10.2019]

2 European Commission, Better regulation - taking stock and sustaining our commitment, Brussels, 2019 , p. 9.

${ }^{3} \mathrm{https://rulemaking.worldbank.org/en/ria-documents} \mathrm{[01.10.2019]}$

4 Organisation for Economic Cooperation and Development, Building a framework for conducting Regulatory Impact Analysis: Tools for policy makers, Paris, 2007.

${ }^{5}$ https://www.sgi-network.org/2019/Governance/Executive_Capacity/Evidence-based_Instruments [01.10.2019]

6 S. Jacobs, Current trends in Regulatory Impact Analysis: the challenges of mainstreaming RIA into policymaking, 2006.
} 


\section{IMPACT EVALUATION IN THEORY}

The European legal literature in the field of evaluation and impact of Structural and Cohesion funds is very limited. Even though, in recent years, the European Commission has gradually strengthened the digitalization of legislation, also managing a specific community law platform ${ }^{7}$ regarding legal regulations, there is still missing the level of intermediary bodies online sources of documentation such as annual implementation reports or evaluation reports at operational and impact program level. There are no clear statistics at the level of the development regions (NUTS 2 territorial level) regarding the individualized implementation of the operational programs and their correlation with the objectives of each Member State's National Strategic Reference Framework or of the Regional Development Plans, the same situation being also reflected at the county level (NUTS 3 territorial level).

From the point of view of European Commission, not every public policy needs to be passed through an impact assessment procedure, because, on one side, it could not give any relevant conclusions, or, on the other side, it would not be possible to evaluate it. 'Between the years 2015 - 2018, $8.5 \%$ of the Commission proposals [...] were not supported by an impact assessment where one might have been expected ${ }^{8}$.

As a definition, impact evaluation allows to check whether funding programs function as intended, 'it identifies problems and their causes that then feed into impact assessments and eventually proposals that can deliver better results; it also provides the evidence needed to simplify and tackle unnecessary costs without undermining policy objectives ${ }^{9}$. But it is also true that there is a need to improve the quality of evaluations (in particular the design, objectivity and timing of an impact assessment method $)^{10}$.

Despite the fact that the European Parliament, the Council and the Commission have adopted the Interinstitutional Agreement on Better Law-Making ${ }^{11}$, in some cases, the Commission does not have adequate information about how Union legislation works in the Member States because 'the legislation as adopted by the co-legislators does not maintain the measures proposed to allow the collection of the data necessary to permit a good evaluation, 12 in the field of impact assessment. In other cases, the co-legislators add 'requirements for a range of different reviews or impose deadlines for evaluating legislation, which fall before there has been enough practical experience of applying the rules ${ }^{13}$.

Another minus is that 'the European Commission impact assessments make better use of evaluations as a basis for problem definition, but the European Parliament and the Council do not generally consider evaluations in their work ${ }^{14}$. Evaluations and impact assessments should be linked better so that findings from one are used more effectively by the other.

'By the end of 2018, the Commission had produced 259 evaluations. About three quarters of impact assessments supporting legislative revisions are now accompanied by an evaluation" ${ }^{, 15}$. The most popular were the counterfactual methods of impact assessment ('with funding scenario' versus 'without funding scenario'), which had the expected effect at the

\footnotetext{
${ }^{7} \mathrm{https}: / /$ webgate.ec.europa.eu/esiflegislation/display/ESIFLEG/ESIF+Legislation+Home [01.10.2019]

${ }^{8}$ European Commission, Better regulation - taking stock and sustaining our commitment, Brussels, 2019, p. 10.

${ }^{9}$ Ibidem.

${ }^{10}$ Organisation for Economic Cooperation and Development, Better regulation practices across the European Union, 2019.

${ }^{11} \mathrm{https}: / /$ eur-lex.europa.eu/legal-content/EN/TXT/?uri=CELEX\%3A32016Q0512\%2801\%29 [01.10.2019]

${ }_{12}^{12}$ European Commission, Better regulation - taking stock and sustaining our commitment, Brussels, 2019, p. 10.

${ }^{13}$ Ibidem.

${ }^{14}$ Ibidem.

${ }^{15}$ Ibidem.
} 
macroeconomic level, when the behavior of counties or regions has been investigated overall. Another area applicable to this type of evaluation is the educational infrastructure, respectively the business environment. However, when it comes to social infrastructure and tourism, it is difficult to quantify the impact of the investments made.

\section{IMPACT EVALUATION IN PRACTICE}

If it were necessary to establish the impact of Structural and Cohesion funds scientifically, the first question would be: how did they contribute to economic development? Due to the co-financing mechanisms, they rather stimulate public investments - in transport infrastructure, environmental protection, renovation of historical heritage, urbanization through water and sewerage systems, waste management, etc. On the other hand, these investments also focus on human development, unemployment reduction and the creation of non-governmental organizations. The investments were also set on the development of information systems in the public administrations and re-technologies in the private sectors.

Both of the community financial assistance towards a Member State, the PreAccession funds and the Structural and Cohesion funds, do not seek to replace the national financing measures but, on the contrary, they come to complement them. It can be specified that, in each Member State, the European Union made its presence felt in the relevant institutional environment and in the specialized economic language from the pre-accession period to the post-accession period, when each Member State had its debut in using these funds, as the national legislation in the field was, in most of the cases, rigid and incomplete, the legal and institutional bases being deepened only after a period of accommodation. From that moment, the concepts in the field of Structural and Cohesion funds began to become more visible, with research concerns beginning to be spotted in this field, because since from the pre-accession years to the post-accession period, it was not known the impact that these funds will generate, there were not identified in realistic terms the potential beneficiaries, the target groups and the economic effects that such projects can generate to the national economy of each Member State, both in macroeconomic and microeconomic perspective.

In the case of Structural and Cohesion funds, the European Commission approaches the impact assessment only at Member State level and uses macroeconomic models, but the results are often questionable (for example, '1 Euro invested in Member States between 2007 and 2013 is equivalent to 0.78 Euro in their GDP in the year 2015, respectively 2.74 Euro in the year $2023^{, 16}$ ). Member States use various econometric analyzes, input-output models, counterfactual methods, SWOT analysis, etc., but also in their case, the results can be called into question. The territorial administrative units, through the representative public institutions, do not approach the evaluation methodologies.

There is a vast and quite clear legislation ${ }^{17}$ in each Member State regarding the management of the non-refundable community assistance, the general financial framework for the management of the non-refundable community assistance allocated to each Member State, the control and recovery of the community funds, the public finances with specific provisions of the external non-refundable funds, the procurement and communication regarding the structural instruments, legislation largely derived from the Union law in this case.

\footnotetext{
${ }^{16}$ F.A. Popescu, M. Berinde, Analysis regarding the instruments for impact evaluation across practitioners, Annals of the University of Oradea - Economic Sciences, TOM XXVI, Issue 1, 2017.

17 e.g. http://mfe.gov.ro/consolidarea-reglementarii-cadrului-de-evaluare-a-impactului-in-romania/ [01.10.2019]
} 
But there is no concrete legislation on choosing an appropriate methodology for assessing the impact of these funds at the macroeconomic level. Indeed, at the microeconomic level, the evaluator of such a project has at its disposal the cost-benefit analysis, the economic and financial analysis, for approving or rejecting the project, instruments derived from the European Union procedures.

It is very difficult, in fact, to assess the economic impact of Cohesion policy, firstly because the data obtained cannot provide clear information on the net effects, at most they can illustrate the result (output) of the funded interventions, and secondly, analytical tools are required, which use technical language and are not accessible to the general public. So far, there is no adaptation in the legal literature of the methodology of impact assessment of Structural and Cohesion on the economy of a region (NUTS 2 territorial level), respectively a county (NUTS 3 territorial level) in any Member State.

\section{CONCLUSIONS}

There is a paradox ${ }^{18}$ specific to the field: although the projects financed through Structural and Cohesion funds generate, in the evaluation phase through the cost-benefit analysis, a clearly identified impact at the target group level, community, actions and benefits taken, the impact assessments fail to capture these elements.

The author estimates that a total contribution to any national economy (e.g. Romanian economy - 53.87 billion Euro $^{19}$ ) through the Cohesion policy has generated significant expenses with bank loans, with the purchase of materials, services and with the staffing necessary for the projects carried out, but it did not have a major impact in the growth of the national GDP, for the following reasons ${ }^{20}$ :

- infrastructure projects, social projects, services and / or equipment endowments do not bring a consistent financial contribution to the state economy;

- the projects which involved the procurement of materials and services, through specific public procurement procedures, shifted the national trade balance towards imports;

- projects on agriculture or zootechnics generate the sale of raw materials or finished products on a market dominated by the presence of imported products;

- investments in industrial parks do not generate a trend of increasing wages.

In order to be able to issue a law establishing the most appropriate methodology for impact assessment at different stages and at subsidiary macroeconomic levels, it is necessary that public institutions who manage Structural and Cohesion funds overcome the passive reporting tendency of the monitored indicators and to adopt an active reporting tendency.

As a critical point of view, the author appreciates that, following the detailed inspection of the lists of projects implemented in some of the Central and South-Eastern Member States, a large part of this funding does not bring a sustainable economic development to the national economies, in the sense that, in the public sector, the vast majority of the portfolio of infrastructure projects consists of objectives delayed by about 5 10 years $^{21}$, in other words, they were not implemented at the right time, and the rehabilitation of roads, buildings or public utility networks would have represented anyway the legal

\footnotetext{
${ }^{18}$ F.A. Popescu, M. Berinde, Theoretical aspects regarding Structural and Cohesion funds impact evaluation methodology, Annals of the University of Oradea - Economic Sciences, TOM XXV, Issue 2, 2016.

${ }^{19} \mathrm{http} / / / \mathrm{mfe} . \mathrm{gov} . \mathrm{ro} /[01.10 .2019]$

20 F.A. Popescu, Impactul fondurilor structurale și de coeziune asupra economiei județului Bihor în perioada 2007-2013, Aureo Publishing House, Oradea, 2019, p. 87.

${ }^{21}$ Ibidem., p. 143.
} 
obligations of city halls or county councils in each Member State. The race over time is lost also in the industry sector, because the settlement of industrial parks, mostly specific for the South-Eastern Member States, is being related more to the decision of the big producing companies to find places with cheap labor force, rather than generating an economic rebirth of some of the lost industrial areas of the country.

In any case, it is worth noting that a possible misalignment of the national strategic objectives of each Member State (as they were transposed in the national operational programs) to the reality of evaluating the projects on the ground, does not necessarily mean that there is a negative side: this denotes that these strategic objectives must keep pace with the dynamics of each Member State's economic development in relation to accelerating the increase in the absorption of Structural and Cohesion funds and, impetuously, they need to be updated in shorter periods of time, and in this regard, impact assessments would help clarifying the overall image.

The author's conclusions are directed towards understanding the antagonism between the negative opinions of worldwide academics and the positive opinions of the public authorities or private consultancy companies, generated by the gradual appearance of the impact assessments. In both cases, however, it is widely accepted that the effect of propagation throughout the community is too widespread and in reality, it is not yet known.

\section{BIBLIOGRAPHY}

European Commission, Better regulation - taking stock and sustaining our commitment, Brussels, 2019, [online] https://ec.europa.eu/info/sites/info/files/better-regulation-takingstock_en_0.pdf [01.10.2019].

F.A. Popescu, Impactul fondurilor structurale și de coeziune asupra economiei județului Bihor în perioada 2007-2013, Aureo Publishing House, Oradea, 2019.

Organisation for Economic Cooperation and Development, Better regulation practices across the European Union, 2019, [online] https://www.oecd-ilibrary.org/governance/betterregulation-practices-across-the-european-union_9789264311732-en [01.10.2019]

F.A. Popescu, M. Berinde, Analysis regarding the instruments for impact evaluation across practitioners, Annals of the University of Oradea - Economic Sciences, TOM XXVI, Issue 1, 2017, pp. 691-696.

F.A. Popescu, M. Berinde, Theoretical aspects regarding Structural and Cohesion funds impact evaluation methodology, Annals of the University of Oradea - Economic Sciences, TOM XXV, Issue 2, 2016, pp. 106-116.

Organisation for Economic Cooperation and Development, Building a framework for conducting Regulatory Impact Analysis: Tools for policy makers, Paris, 2007, [online] https://www.oecd.org/mena/governance/38706266.pdf [01.10.2019].

S. Jacobs, Current trends in Regulatory Impact Analysis: the challenges of mainstreaming RIA into policy-making, 2006, [online] http://regulatoryreform.com/wp-content/uploads/ 2014/11/Jacobs_Current_Trends_and_Processes_in_RIA_May_2006.pdf [01.10.2019]. https://ec.europa.eu/regional_policy/ro/information/legislation/regulations/ [01.10.2019] https://eur-lex.europa.eu/legal-content/EN/TXT/?uri=CELEX\%3A32016Q0512\%2801\%29 [01.10.2019]

http://mfe.gov.ro/consolidarea-reglementarii-cadrului-de-evaluare-a-impactului-in-romania/ [01.10.2019]

http://mfe.gov.ro/ [01.10.2019]

https://rulemaking.worldbank.org/en/ria-documents [01.10.2019]

https://www.sgi-network.org/2019/Governance/Executive_Capacity/Evidence-

based_Instruments [01.10.2019] 
Felix-Angel Popescu

https://webgate.ec.europa.eu/esiflegislation/display/ESIFLEG/ESIF+Legislation+Home [01.10.2019] 